\title{
Identifikasi Geologi Lingkungan Pada Evaluasi Tapak Fasilitas Industri Nuklir BNI-STP, Penajam Paser Utara
}

\author{
Heni Susiati ${ }^{{ }^{1}}$, Herning Dyah Kusuma ${ }^{2}$, Hil Gendoet Hartono ${ }^{3}$, Sriyana ${ }^{4}$ \\ ${ }^{1,4}$ Pusat Kajian Sistem Energi Nuklir, BATAN, Jalan Kuningan Barat, Mampang Prapatan, Jakarta Selatan 12710 \\ ${ }^{2,3}$ STTNAS Yogyakarta, Jalan Babarsari, Depok, Sleman, Yogyakarta
}

\begin{tabular}{l}
\hline INFORMASI ARTIKEL \\
\hline Riwayat Artikel:
\end{tabular}

Kata kunci:

geologi lingkungan

BNI-STP

tapak

fasilitas nuklir

\begin{abstract}
ABSTRAK
IDENTIFIKASI GEOLOGI LINGKUNGAN PADA EVALUASI TAPAK FASILITAS INDUSTRI NUKLIR BNI-STP, PENAJAM PASER UTARA. Terkait dengan rencana pengembangan industri kenukliran di Buluminung yaitu BNI-STP (Buluminung Nuclear Industry-Science Technology Park), telah dilakukan survei tapak, khususnya identifikasi karakteristik geologi lingkungan. Tujuan penelitian adalah memperoleh data baseline karakteristik geologi lingkungan yang meliputi indentifikasi data stratigrafi (litologi, susunan perlapisan tanah/ batuan), struktur geologi, vulkanologi, topografi, kegempaan, dan hidrogeologi. Metodologi meliputi studi literatur dan pengamatan di lapangan yaitu identifikasi karakteristik kondisi geologi terkait struktur geologi, stratigrafi (litologi dan susunan pelapisan tanah/batuan), vulkanologi, topografi, kegempaan dan hidrogeologi. Hasil identifikasi menunjukkan bahwa karakteristik geologi lingkungan kawasan fasilitas industri nuklir BNI-STP adalah struktur kekar berarah relatif utara selatan dan struktur sayap lipatan yang berarah timurlaut-baratdaya yang terbentuk pada masa Mio-Pliosen. Litologi penyusunnya berupa batupasir, serpih dan batubara yang termasuk dalam Formasi Balikpapan, sedangkan sebagian area lainnya ditutupi oleh endapan sungai lempung dan endapan rawa. Selain itu tidak dijumpai indikasi adanya struktur tektonik aktif maupun vulkanisme aktif. Topografi area BNI-STP adalah datar, dan kondisi hidrogeologinya dengan sistem akuifer sedang, dan kondisi kegempaan aman dari pusat gempa.
\end{abstract}

\begin{abstract}
IDENTIFICATION OF ENVIRONMENTAL GEOLOGY IN SITE LOCATION OF NUCLEAR INDUSTRY FACILITIES BNI-STP, PENAJAM PASER UTARA. In relation to the development plan of BNI-STP (Buluminung Nuclear Industry-Science Technology Park), the site survey has been conducted, especially the identification of environmental geological characteristics. The research objectives are to obtain baseline data of environmental geological characteristics which include identification of stratigraphic data (lithology, soil / rock layer), geological structure, volcanology, topography, seismicity, and hydrogeology. Methodology includes literature study and field observation such as identification of geological characteristics related to geological structure, stratigraphy (lithology and soil / rock sequence), volcanology, topography, seismicity and hydrogeology. Site evaluation methodologies were conducted with literature and field geology studies. The results of field literature and field geology indicate that the data of environmental geological characteristics in the BNI-STP nuclear facility area of relatively southern south-trending direction and the northeast-southwest trending wing structure formed at the Mio-Pliocene period. Composite lithology of BNI-STP area is sandstone, shale and coal which is included in Balikpapan Formation. Some areas are covered by clay river deposits and swamp deposits. moreover, there is no indication of active fault or active volcanism. The topography is relatively flat, and its hydrogeological conditions with medium aquifers, and seismic conditions are safe from the epicenter.

Keywords: geology environment, BNI-STP, site, nuclear facility
\end{abstract}

\section{PENDAHULUAN}

Kabupaten Penajam Paser Utara (PPU) merupakan salah satu kabupaten yang terdapat di Provinsi Kalimantan Timur bagian selatan, berada di bagian pesisir sebelah timur Pulau Kalimantan, berseberangan dengan Kota Balikpapan. Selain akan dibangun kawasan industri Buluminung, Pemerintah Daerah Kalimantan Timur juga akan mengembangkan Pusat Nasional Techno Park (NSTP) Teknologi dan Industri Nuklir atau BNI-STP
(Buluminung Nuclear Industry and Science Technology Park) untuk mendukung program nuklir di Kalimantan Timur[1].

Kawasan Buluminung, Kecamatan Penajam, Kabupaten PPU, Kalimantan Timur telah ditetapkan sebagai kawasan industri guna meningkatkan pertumbuhan sektor industri yang lebih terarah, terpadu dan optimal. Buluminung akan dikembangkan sebagai kawasan terpadu dengan berbagai 
fasilitas berbasis iptek nuklir, dalam satu tatanan yang saling bersinergi[2]. Area BNISTP ini direncanakan akan difungsikan sebagai pusat pendidikan, pelatihan, dan pengembangan SDM berkompetensi iptek nuklir. Selain itu BNI-STP juga sebagai pusat aplikasi iptek nuklir di berbagai bidang industri, kesehatan, pangan, energi, air, pertambangan dan lingkungan, dalam rangka industrialisasi berwawasan lingkungan. Wilayah Buluminung dipilih karena kawasan ini sangat strategis dan memiliki daya dukung yang sangat mumpuni, seperti sarana jalan penghubung antar wilayah dan sebagainya. Selain itu, pusat penelitian ini juga memiliki fungsi yang lebih beragam, mulai dari pertanian, perikanan, dan sebagainya[1].

Proses pembangunan Fasilitas Nuklir seperti PLTN, Fabrikasi Bahan Bakar Nuklir, Produksi Radioisotop, Iradiator dll. harus melalui beberapa tahapan, seperti penentuan tapak (survei tapak), konstruksi, komisioning, operasi dan dekomisioning [3]. Kegiatan survei tapak fasilitas nuklir ini dilakukan guna menindaklanjuti survei awal pemilihan lokasi rencana tapak BNI-STP di Kabupaten PPU, Provinsi Kalimantan Timur. Pelaksanaan survei tapak mengacu pada peraturan, pedoman dan standar nasional Badan Pengawas Tenaga Nuklir (BAPETEN) dan Kementrian Lingkungan Hidup dan Kehutanan (KLHK), maupun standar internasional (IAEA) [4].

Penentuan tapak merupakan kegiatan pengumpulan data, konfirmasi lapangan, seleksi, dan evaluasi di lokasi yang akan digunakan untuk pembangunan. Dalam studi evaluasi tapak, data geologi dapat memberikan bobot tinggi untuk menentukan apakah daerah tersebut layak digunakan sebagai lokasi pembangunan atau tidak, walaupun tidak akan mengabaikan data aspek penting lainnya.

Penelitian ini bertujuan untuk identifikasi geologi lingkungan dengan melakukan identifikasi struktur geologi dan satuan batuan, serta sistem sesar yang berkembang di daerah penelitian. Manfaat penelitian adalah memperoleh data baseline karakteristik aspek geologi lingkungan, meliputi data stratigrafi (litologi, susunan perlapisan tanah/ batuan), struktur geologi, vulkanologi, topografi, kegempaan, dan hidrogeologi. Kondisi dan karakteristik geologi lingkungan pada suatu lokasi merupakan aspek penting terkait tingkat kestabilan suatu konstruksi. Data geologi dapat memberikan informasi kekuatan dan karakteristik lapisan tanah/ batuan yang berguna dalam perencanaan dan penataan ruang [5].

\section{POKOK BAHASAN}

\subsection{Kawasan Industri Buluminung}

Di dalam Rencana Tata Ruang Wilayah (RTRW) Provinsi Kalimantan Timur tahun 2016-3026 [2] dan Kabupaten PPU tahun 20112031, disebutkan bahwa akan dikembangkan kawasan industri di Kecamatan Penajam, PPU, Kaltim, salah satunya adalah kawasan industri Buluminung (Gambar 1). Masterplan Pengembangan Kawasan Industri Buluminung ditujukan untuk mempercepat pertumbuhan sektor industri, memberikan kemudahan bagi kegiatan industri, mendorong kegiatan industri untuk berlokasi pada kawasan yang telah direncanakan, dan menyediakan fasilitas-utilitas industri yang berwawasan lingkungan, serta untuk menggerakkan pertumbuhan ekonomi dan perluasan kesempatan kerja guna peningkatan kesejahteraan masyarakat di Kabupaten PPU. Di dalam kawasan industri tersebut juga akan dikembangkan kawasan fasilitas nuklir yang dinamakan BNI-STP.

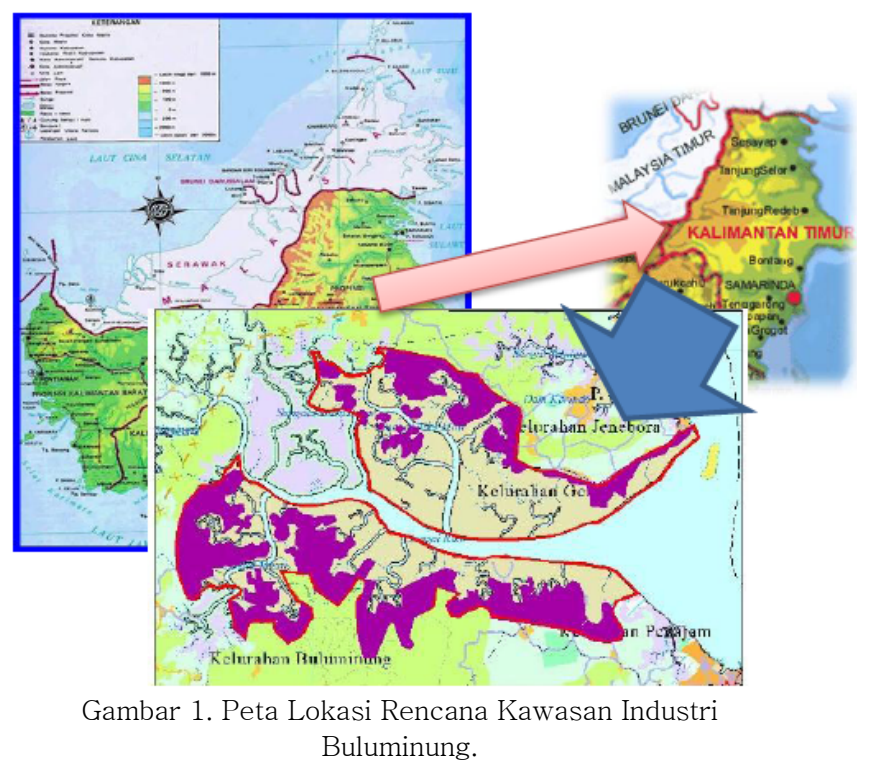

Kawasan BNI-STP merupakan area terpadu berbagai fasilitas berbasis iptek 
nuklir dalam satu tatanan yang saling bersinergi[6]. Kawasan ini diharapkan dapat menjadi fasilitas dilaksanakannya kegiatan sebagai berikut:

- Kegiatan pendidikan, pelatihan dan pengembangan (DiklatBang) SDM berkompeternsi IPTEK nuklir.

- Kegiatan riset, pengembangan dan inovasi produk (barang dan jasa).

- Kegiatan aplikasi IPTEK nuklir di berbagai bidang (industri, kesehatan, pangan, energi, air, pertambangan dan lingkungan).

- Kegiatan untuk mensinergikan IPTEK nuklir dengan dunia usaha.

- Kegiatan promosi dan wisata IPTEK nuklir.

Untuk menunjang kegiatan tersebut, pada lokasi ini direncanakan dibangun kelompok fasilitas utama dan fasilitas umum.

\subsection{Geologi Regional}

Parameter Geologi Lingkungan merupakan salah satu parameter penting dalam melakukan evaluasi tapak fasilitas nuklir. Struktur Geologi daerah penelitian termasuk dalam geologi lembar Balikpapan. Batuan di daerah ini hampir semuanya mengalami deformasi, mulai dari yang Pra-Tersier sampai Tersier Akhir. Akibat proses tersebut terbentuklah antiklin, sinklin dan sesar. Perlipatan pada batuan Tersier membentuk kemiringan antara 10-60 derajat dan pada PraTersier lebih besar dari 40 derajat. Bentuk lipatan umumnya tak setangkup dengan kemiringan lapisan bagian dalam lebih terjal dari pada bagian luar. Arah sumbu lipatannya mulai utara-selatan sampai timurlaut-baratdaya. Struktur sesar daerah ini terdiri atas sesar turun, sesar naik dan sesar geser jurus. Arah sesar-sesar hampir sama dengan arah sumbusumbu lipatan[7].

Kegiatan tektonik daerah ini diduga berlangsung semenjak Jura. Akibatnya batuan yang berumur pra-Jura, yaitu batuan ultrabasa mengalami alih tempat, perlipatan dan pensesaran. Proses ini diikuti oleh kegiatan magma, kemudian terjadi pengendapan sedimen klastik dan vulkanik yang menyusun formasi Pitap dan formasi Haruyan sebagai batuan tetap-asal pada Kapur Akhir[8]. Kegiatan tektonik pada Kapur Akhir bagian bawah menghasilkan pengalihan tempat batuan ultrabasa oleh sesar naik. Proses itu diikuti dengan kegiatan magma yang menghasilkan terobosan granit, granodiorit dan diorit pada Kapur Akhir[7]. Sejak Paleosen Awal sampai Eosen Awal terjadi pengangkatan, erosi dan pedataran menghasilkan sedimen darat yang menyusun formasi Tanjung dan formasi Kuaro. Berdasarkan cekungan Tersier di Kalimantan Tenggara di beberapa tempat terendapkan karbonat membentuk formasi Tanjung [7].

Pada kala Oligosen hingga Awal Miosen terjadi penurunan terus menerus yang berlangsung sampai Miosen Awal. Bahan yang terendapkan berasal dari bagian selatan, barat dan utara cekungan. Fasies susut laut terbentuk di bagian terdalam cekungan tersebut. Di bagian selatan cekungan endapan ini mempunyai hubungan dengan perkembangan fasies karbonat yang menyusun formasi Berai bersamaan dengan perkembangan sedimen klastika ke arah tengah cekungan yang menyusun formasi Pamaluan[7].

Pada Kala Miosen Tengah terjadi susut laut yang mengakibatkan terbentuknya endapan darat yang menyusun formasi Warukin, Pulau Balang dan Balikpapan. Pada kala Miosen Akhir terjadi lagi pengangkatan yang menyebabkan terjadinya sesar bongkah dan munculnya kembali batuan tua termasuk batuan replacement sehingga terbentuk Tinggian Meratus. Akibatnya terbentuklah cekungan Barito, Kutai dan anak cekungan Pasir yang disertai pengendapan[7].

Gerak tektonik kuat ini mengangkat tepi cekungan sebelah barat yang menghasilkan pengendapan sedimen klastik ke arah timur yang diikuti kegiatan vulkanik berupa penerobosan di Purukcahu dan pelelehan lava serta pengendapan tufa di daerah Lembak. Pengendapan sedimen klastika di lembar Balikpapan menghasilkan endapan delta dari formasi Kampungbaru di cekungan Kutai[7,8].

\section{METODOLOGI}

\subsection{Bahan dan Peralatan}

Pada penelitian ini digunakan bahan dan peralatan sebagai berikut:

- Peta geologi dan peta dasar rupa bumi/ topografi Kabupaten Penajam Paser 
Utara skala 1: 250.000 untuk kegiatan evaluasi daerah penelitian BNI-STP.

- Komparator butir batuan sedimen dan larutan $\mathrm{HCl}$.

- Global Positioning System (GPS), kompas geologi, palu geologi, kaca pembesar, dan kamera.

- Komputer dan perangkat lunak ArcGis untuk mengolah data dan pemetaan data hasil identifikasi lapangan.

\subsection{Tata Kerja}

Pada penelitian ini dilakukan:

- Pengamatan lapangan

- Identifikasi karakteristik.

Identifikasi dilakukan secara deskriptif terhadap kondisi geologi regional Pulau Kalimantan, khususnya wilayah Kabupaten Penajam Paser Utara menggunakan peta Geologi Regional berskala 1:250.000 yang meliputi lembar Balikpapan. Data geologi regional diperoleh dari kajian studi pustaka beberapa peneliti sebelumnya.

- Pengolahan hasil ploting lapangan dan pemetaan dengan program ArcGIS.

- Evaluasi kondisi geologi regional terkait struktur geologi, stratigrafi dan aspek vulkanologi.

\subsection{Daerah Penelitian}

Penelitian geologi lingkungan dilakukan di area lokasi BNI-STP, dan letak lokasi pengamatan meliputi site area dan regional area (Gambar 2).

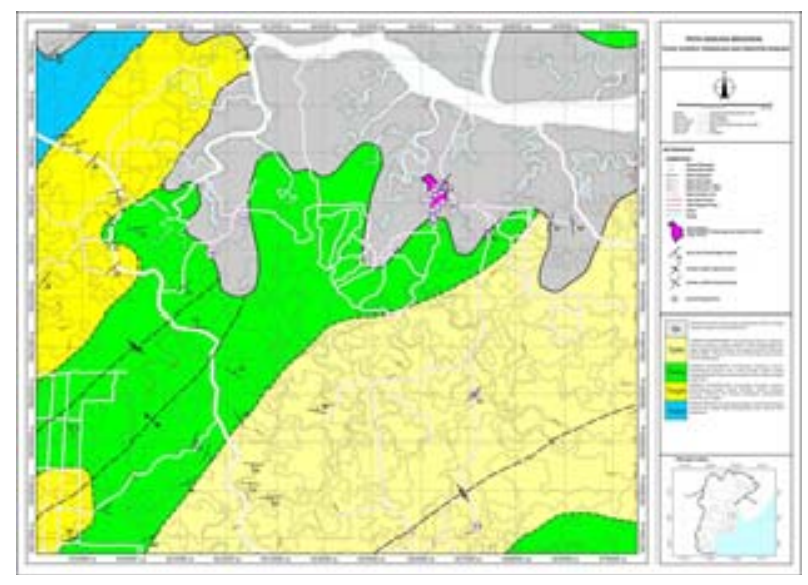

Gambar 2. Peta Geologi Regional Daerah Penelitian[9]
Berdasarkan peta geologi lembar Balikpapan skala 1:250.000, stratigrafi regional daerah penelitian dan sekitarnya tersusun oleh Formasi Bebulu, Pulaubalang, Balikpapan dan Kampung Baru serta endapan aluvial (Gambar 2) [8].

Formasi Bebulu merupakan formasi tertua berumur Miosen Awal bagian atas yang tersusun atas batugamping dengan sisipan batulempung lanauan dan sedikit napal. Formasi Pulaubalang berumur Miosen Tengah merupakan perselingan batupasir kuarsa, batulempung dengan sisipan batubara. Formasi Balikpapan berumur Miosen Tengah bagian atas tersusun oleh batupasir kuarsa, batulempung lanauan, serpih dengan sisipan napal, batugamping dan batubara. Formasi Kampung Baru berumur Mio-Pliosen tersusun oleh batulempung pasiran, batupasir kuarsa, batulanau, sisipan batubara, napal batugamping dan lignit. Formasi ini terletak tidak selaras di atas Formasi Balikpapan.

\section{HASIL DAN PEMBAHASAN}

\subsection{Kondisi Kelerengan}

Hasil pengamatan lapangan diperoleh kondisi penggunaan lahan eksisting di calon lokasi Kawasan Industri Buluminung masih berupa hutan mangrove yang jumlahnya mencapai 54\%. Di kawasan peruntukan industri ini, juga sudah banyak berdiri industri berskala besar.

Hasil pengamatan di lapangan dan evaluasi terhadap kelerengan serta bentang alam Kawasan Industri Buluminung, menunjukkan secara morfologis merupakan dataran dengan sedikit perbukitan dengan kelerengan berkisar antara 0-15\% (kestabilan lereng tinggi) hanya sekitar $29 \%$ dari luas wilayah, kelerengan $15-25 \%$ seluas $12 \%$, dan sisanya merupakan kawasan dengan kelerengan antara 25\% - >40\%, dengan total luas lebih dari $58 \%$ dari luas kawasan industri yang akan dikembangkan.

\subsection{Studi Regional}

Penelitian geologi dimulai dari identifikasi tektonik dan struktur geologi secara regional berdasarkan data sekunder 
peta geologi, publikasi peneliti terdahulu dan dari rekaman seismisitas atau kegempaan. Hasil penelitian regional ini dipakai sebagai pembanding dalam melihat hasil penelitian lokal.

Bukti adanya pergerakan tektonik ditunjukkan dari rekaman kegempaan maupun bukti lapangan, seperti keberadaan struktur patahan, lipatan, maupun kekar.

Berdasarkan penelitian regional Wain \& Berod (1989)[9], Satyana (1996)[10] dan Moss \& Chamber (1999)[11], bahwa sekitar $70 \mathrm{~km}$ ke arah selatan daerah penelitian diinterpretasikan terdapat struktur Sesar Adang yang berarah barat laut-tenggara. Sesar besar ini digambarkan memotong Pulau Kalimantan yang membatasi Tinggian Paternosfer di bagian lepas pantai hingga memisahkan Cekungan Kutai dan Barito di daratan Kalimantan (Gambar 3).

Pada umur saat Eosen-Oligosen, keberadaan Sesar Adang diperkirakan mengontrol pola sedimentasi di daerah sekitarnya. Mulai pada Miosen akhir, sesar ini kembali mengalami pergerakan secara lateral yang umumnya bergerak geser kiri mengakomodasi gaya kompresional akibat kolisi Kontinen Australia dengan Busur Banda.

Hasil penelitian yang telah dilakukan oleh peneliti sebelumnya, memperlihatkan bahwa Sesar Adang mengalami percabangan menjadi beberapa sesar (splay) di sekitar lepas pantai selatan Balikpapan hingga ke daratan, diantaranya adalah Sesar Sepinggan, Bungur dan Tengah (Gambar 4)[12,13].

Keberadaan sesar-sesar tersebut diinterpertasikan dari hasil analisis data seismik di lepas pantai maupun di darat dan ditunjukkan juga dengan adanya perubahan orientasi sumbu lipatan antara Samarinda
Antiklinorium di bagian utara sesar yang berarah relatif selatan baratdaya-utara timurlaut dengan Adang Antiklinorium yang relatif berarah baratdaya-timurlaut di bagian selatannya.

Identifikasi seismisitas regional daerah BNI-STP yang terletak di timur Pulau Kalimantan didasarkan dari data Badan Meteorologi, Klimatologi dan Geofisika (BMKG)[14]. Getaran seismik atau gempa dapat berasal dari pergerakan lempeng tektonik atau adanya aktifitas volkanik.

Berdasarkan data, sejarah seismisitas atau kegempaan di daerah ini, tidak banyak dijumpai atau termasuk dalam area yang relatif stabil. Letak Pulau Kalimantan tidak berbatasan langsung dengan zona penunjaman lempeng aktif, sehingga mendukung stabilnya tektonik di daerah ini. Namun interpretasi seismik di lepas pantai Balikpapan menunjukkan bahwa pada horison atas dekat dengan (sea bed) atau pada stratigrafi yang muda telah mengalami proses pensesaran awal (immature fault) yang berhubungan dengan Sesar Sepinggan, Bungur dan Tengah. Pendugaan keberadaan sesar pada studi awal ini, diperlukan kajian lebih lanjut terkait ada tidaknya pergerakan sesar[13].

Aktifitas vulkanisme terekam sekitar $100 \mathrm{~km}$ baratlaut dari daerah penelitian, yakni vulkanisme di daerah Kelian, Muara Teweh, yang berumur mulai Oligosen Akhir hingga Miosen Awal. Proses vulkanisme ini oleh peneliti sebelumnya telah dikorelasikan dengan proses magmatisme terkait "rifting" di Kalimantan yang berarah baratlauttenggara[10,16]. Vulkanisme berumur PlioPleistosen juga dijumpai di daerah Kelian[17]. 


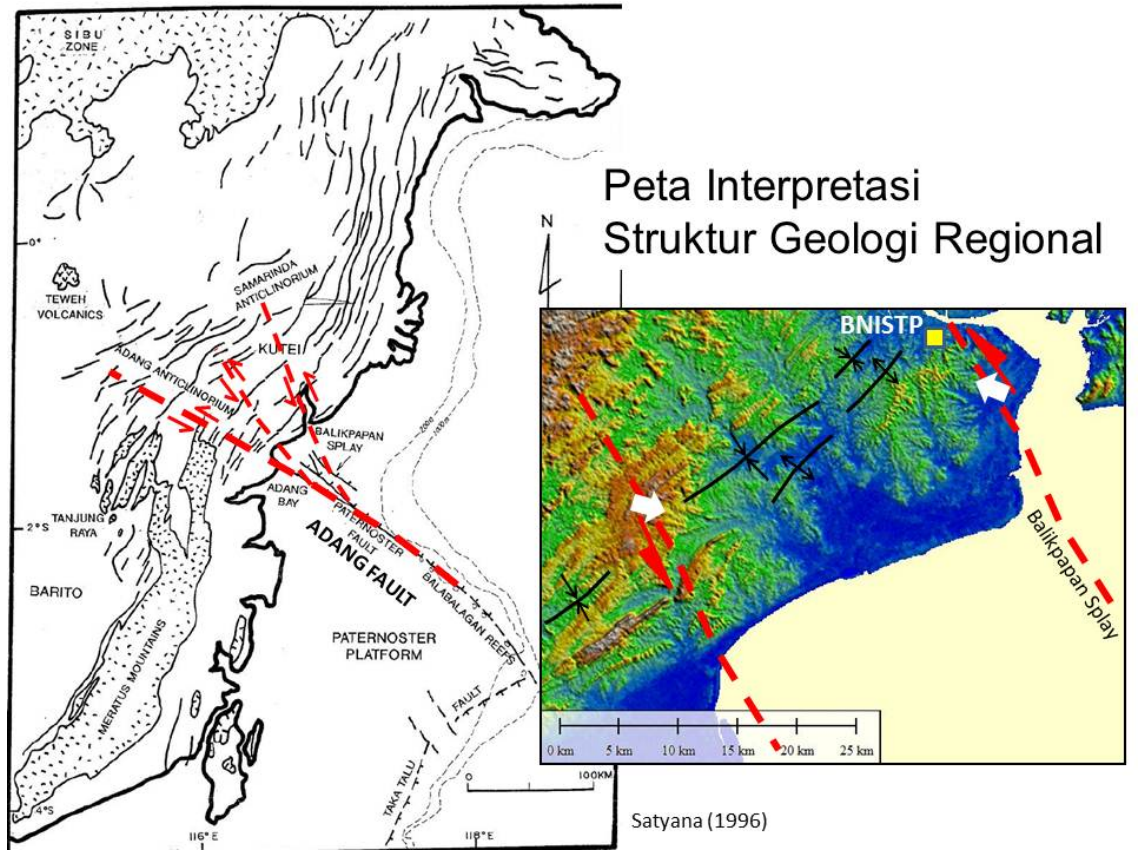

Gambar 3. Tatanan Geologi Regional Pulau Kalimantan[10]

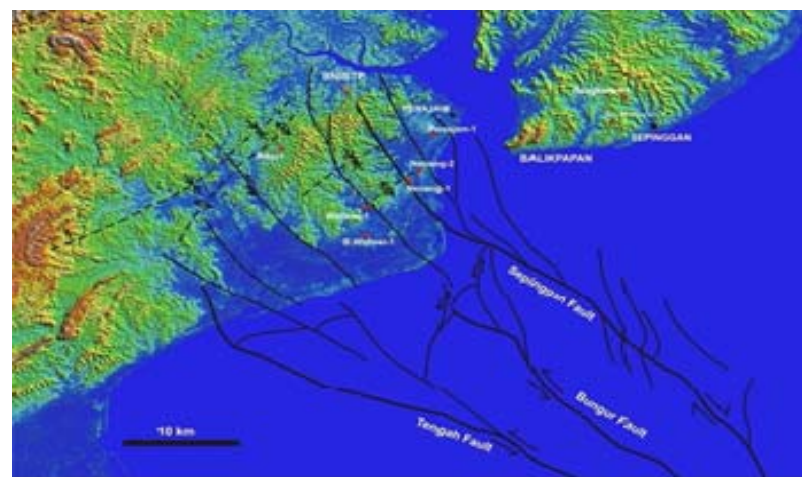

Gambar 4. Interpretasi Struktur Percabangan Sesar Adang (Modifikasi dari Susianto, 2012) dalam Peta Shuttle Radar Topography Mission (SRTM) Resolusi 30m (USGS, 2017) $[13,15]$

4.3. Identifikasi Geologi Lapangan dan Pengamatan Geologi Lingkungan

Identifikasi geologi lapangan dilakukan dengan pengamatan singkapan di beberapa lokasi pengamatan (LP). Letak lokasi pengamatan sebagian berada di site area maupun regional area (luar) BNI-STP. Berdasarkan hasil pengamatan diketahui bahwa morfologi area penelitian merupakan dataran bergelombang dengan beberapa rawa dijumpai pada bagian tengah area. Di bagian barat, area ini berbatasan dengan anak sungai Riko. Elevasi area rata-rata berkisar 15-40 m dengan elevasi tertinggi $40 \mathrm{~m}$ dan area terendah sekitar $8 \mathrm{~m}$ (Gambar 5).
Struktur geologi yang dijumpai di lokasi penelitian adalah kekar, seperti pada LP 6 . Kekar yang berarah relatif utara-baratlaut selatan-tenggara hampir searah dengan interpretasi keberadaan sesar dari percabangan Sesar Sepinggan di area sekitar BNI-STP (Gambar 5). Sesar tersebut berdasarkan studi pustaka aktif pada masa Miosen[13,15]. Pada masa sekarang belum ada penelitian atau data yang menunjukkan bukti pergerakan dari sesar sehingga diperkirakan sesar tersebut kini tidak aktif.

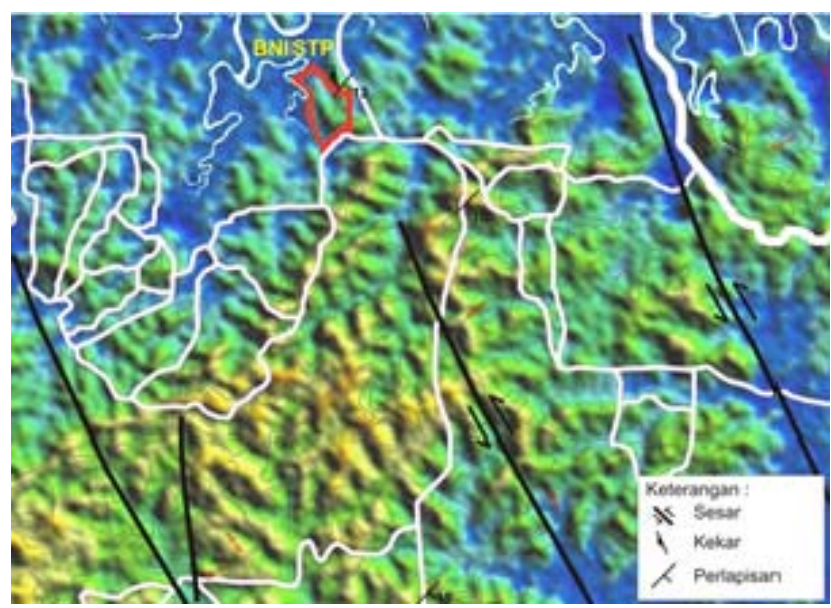

Gambar 5. Interpretasi Struktur Sesar Di Area Sekitar BNI-STP Berdasarkan Penelitian Regional Dalam Peta Shuttle Radar Topography Mission (SRTM). 
Tabel 1. Data Litologi dan Morfologi Lokasi Penelitian

\begin{tabular}{|c|c|c|c|c|}
\hline \multirow{2}{*}{$\begin{array}{l}\text { Lokasi } \\
\text { Peneliti } \\
\text { an }\end{array}$} & \multicolumn{2}{|c|}{ Koordinat } & \multicolumn{2}{|l|}{ Keterangan } \\
\hline & $\begin{array}{c}\mathrm{X} \\
\text { (Timur) }\end{array}$ & $\begin{array}{c}\mathrm{Y} \\
\text { (Utara) }\end{array}$ & Litologi & Morfologi \\
\hline 1. & 466699 & $\begin{array}{c}98639 \\
29\end{array}$ & $\begin{array}{l}\text { Batupasir kuarsa yang sebagian telah mengalami } \\
\text { pelapukan menjadi tanah. Warna batupasir lapuk } \\
\text { coklat kemerah-merahan, ukuran butir pasir halus } \\
\text { hingga sangat halus. Komposisi utama adalah } \\
\text { kuarsa. }\end{array}$ & $\begin{array}{l}\text { terletak di bagian tenggara area } \\
\text { BNI-STP, di pinggir jalan } \\
\text { perkebunan sawit, jalan hauling } \\
\text { tambang PT. PPC. Morfologi } \\
\text { dataran-bergelombang. }\end{array}$ \\
\hline 2. & 466458 & $\begin{array}{c}98639 \\
56\end{array}$ & $\begin{array}{l}\text { Batupasir dan pada beberapa bagian struktur } \\
\text { sedimen berupa laminas.. Warna batupasir lapuk } \\
\text { coklat kemerah-merahan, warna relatif segar putih } \\
\text { kecoklatan, ukuran butir pasir halus. Komposisi } \\
\text { batuan didominasi oleh kuarsa }\end{array}$ & $\begin{array}{lll}\text { terletak di bagian selatan area } \\
\text { BNI-STP, di pinggir jalan } \\
\text { perkebunan } & \text { sawit. Morfologinya } \\
\text { dataran. } & \end{array}$ \\
\hline 3. & 466342 & $\begin{array}{c}98638 \\
50\end{array}$ & $\begin{array}{l}\text { Batupasir, yang sebagian telah mengalami pelapukan } \\
\text { menjadi tanah di bagian atas. Warna batupasir lapuk } \\
\text { putih kecoklat-coklatan dengan warna relatif segar } \\
\text { putih. Ukuran butir batupasir adalah halus dan } \\
\text { komposisi didominasi oleh kuarsa. }\end{array}$ & $\begin{array}{l}\text { terletak di bagian selatan area } \\
\text { BNI-STP. di pinggir jalan } \\
\text { perkebunan sawit. Morfologinya } \\
\text { dataran dengan singkapan tebing } \\
\text { bukaan jalan dan dimensi tinggi } \\
\text { sekitar } 2,5 \mathrm{~m} \text {. }\end{array}$ \\
\hline 4. & 466278 & $\begin{array}{c}98637 \\
97\end{array}$ & $\begin{array}{l}\text { Batupasir yang sebagian besar telah mengalami } \\
\text { pelapukan menjadi tanah. Warna batupasir lapuk } \\
\text { putih kecoklat-coklatan hingga coklat kemerah- } \\
\text { merahan. Ukuran butir batupasir adalah pasir halus } \\
\text { - sangat halus dan komposisi didominasi oleh } \\
\text { kuarsa. }\end{array}$ & $\begin{array}{l}\text { terletak di bagian selatan area } \\
\text { BNI-STP, di pinggir jalan } \\
\text { perkebunan sawit. Morfologinya } \\
\text { dataran dekat dengan aliran anak } \\
\text { sungai. }\end{array}$ \\
\hline 5. & 466281 & $\begin{array}{c}98635 \\
60\end{array}$ & $\begin{array}{l}\text { Batupasir, warna batupasir lapuk coklat kemerah- } \\
\text { merahan (Gambar 10). Ukuran butir batupasir adalah } \\
\text { pasir halus - sangat halus dan komposisi didominasi } \\
\text { oleh kuarsa }\end{array}$ & $\begin{array}{l}\text { terletak di bagian selatan area } \\
\text { BNI-STP, di pinggir jalan } \\
\text { perkebunan sawit. Morfologinya } \\
\text { dataran dan singkapannya berupa } \\
\text { tebing bukaan jalan setinggi } \\
\text { sekitar } 3 \mathrm{~m} \text {. }\end{array}$ \\
\hline 6. & 466435 & $\begin{array}{c}98643 \\
59\end{array}$ & $\begin{array}{l}\text { Batupasir, serpih, perlapisan } \mathrm{N} 40^{\circ} \mathrm{E} / 12^{\circ}, \text { Kekar } \\
\mathrm{N} 175^{\circ} \mathrm{E}-\mathrm{N} 170^{\circ} \mathrm{E} / 75^{\circ} \text {. }\end{array}$ & $\begin{array}{l}\text { terletak di bagian timur laut area } \\
\text { BNI-STP, di pinggir sebelah barat } \\
\text { jalan hauling PT. PPC. } \\
\text { Morfologinya dataran- } \\
\text { bergelombang. Singkapan berupa } \\
\text { tebing bukaan jalan dan bekas } \\
\text { bukaan tambang. Kedudukan } \\
\text { perlapisan batuan hasil } \\
\text { pengukuran adalah } \mathrm{N} 40^{\circ} \mathrm{E} / 2^{\circ} \\
\text { atau kemiringan relatif ke arah } \\
\text { tenggara. }\end{array}$ \\
\hline 7. & 467423 & $\begin{array}{c}98633 \\
94\end{array}$ & Batu pasir, serpih, perlapisan N45E/10 & $\begin{array}{l}\text { terletak di bagian tenggara area } \\
\text { BNI-STP, berada di pinggir } \\
\text { sebelah timur jalan hauling PT. } \\
\text { PPC. Morfologi daerah sekitar } \\
\text { adalah bergelombang. }\end{array}$ \\
\hline 8. & 466364 & $\begin{array}{c}98643 \\
00\end{array}$ & $\begin{array}{l}\text { Rawa-1, lokasi terletak di dalam area BNI-STP. } \\
\text { Morfologi berupa dataran. Dijumpai rawa dengan } \\
\text { kedalaman sekitar } 0.4 \mathrm{~m} \text {. Litologi tidak nampak } \\
\text { karena tertutup rawa }\end{array}$ & $\begin{array}{l}\text { terletak di dalam area BNI-STP. } \\
\text { Morfologi berupa dataran. } \\
\text { Dijumpai rawa dengan kedalaman } \\
\text { sekitar } 0,4 \mathrm{~m} \text {. }\end{array}$ \\
\hline 9. & 466336 & $\begin{array}{c}98642 \\
89\end{array}$ & Litologinya tidak nampak karena tertutup rawa & $\begin{array}{l}\text { terletak di dalam area BNI-STP. } \\
\text { Morfologinya berupa dataran, } \\
\text { rawa dengan kedalaman sekitar } \\
0,5 \mathrm{~m} \text {. }\end{array}$ \\
\hline 10. & 466246 & $\begin{array}{c}98641 \\
27\end{array}$ & $\begin{array}{l}\text { Litologi berupa tanah lapukan batupasir berwarna } \\
\text { coklat kemerah-merahan dan endapan rawa } \\
\text { berwarna coklat gelap }\end{array}$ & $\begin{array}{l}\text { terletak di dalam area BNI-STP. } \\
\text { Morfologi berupa dataran. } \\
\text { Dijumpai rawa dengan kedalaman } \\
\text { sekitar } 0,2 \mathrm{~m} \text {. }\end{array}$ \\
\hline 11. & 466164 & $\begin{array}{l}98639 \\
96\end{array}$ & Endapan lempung, Anak sungai Riko & $\begin{array}{l}\text { terletak di bagian barat area BNI- } \\
\text { STP. Morfologi berupa lembah } \\
\text { anak sungai Riko. }\end{array}$ \\
\hline 12. & 467114 & $\begin{array}{c}98599 \\
90\end{array}$ & $\begin{array}{l}\text { Batupasir, batu lempung, perlapisan } \mathrm{N} 46^{\circ} \mathrm{E} / 15^{\circ} \text {, } \\
\text { berwarna abu-abu dengan struktur laminasi. Tebal } \\
\text { lapisan di bagian bawah ini sekitar } 1,5 \mathrm{~m} \text {. Di atasnya }\end{array}$ & $\begin{array}{l}\text { terletak sekitar } 4 \mathrm{~km} \text { di bagian } \\
\text { tenggara area BNI-STP, berada } \\
\text { di pinggir sebelah timur jalan }\end{array}$ \\
\hline
\end{tabular}




\begin{tabular}{|c|c|c|c|c|}
\hline & & & $\begin{array}{l}\text { dijumpai tiga lapisan batupasir berwarna coklat } \\
\text { muda yang masing masing dibatasi oleh lapisan tipis } \\
\text { oksida besi. Tebal setiap lapisan batupasir berkisar } \\
1,5-2 \text { m sedangkan lapisan oksida besi sekitar } 2-3 \\
\text { cm. Batupasir berukuran pasir halus dengan } \\
\text { komposisi dominan kuarsa. }\end{array}$ & $\begin{array}{lll}\text { hauling. } & \text { Morfologinya } & \text { berupa } \\
\text { dataran. } & & \end{array}$ \\
\hline 13. & 467182 & $\begin{array}{c}98572 \\
48\end{array}$ & $\begin{array}{l}\text { Batupasir, serpih, batubara, tambang batubara PT. } \\
\text { PPC }\end{array}$ & $\begin{array}{lrr}\text { terletak sekitar } 7 & \mathrm{~km} \text { di bagian } \\
\text { selatan area } & \text { BNI-STP, } \\
\text { merupakan lokasi } & \text { penambangan } \\
\text { batubara PT. PPC. Morfologinya } \\
\text { berupa dataran-bergelombang. } \\
\text { Singkapan berupa tebing bukaan } \\
\text { tambang }\end{array}$ \\
\hline 14. & 461652 & $\begin{array}{c}98629 \\
31\end{array}$ & $\begin{array}{l}\text { Batupasir, serpih, batubara, batugamping, tambang } \\
\text { batubara PT. ENA. Litologi yang dapat diamati } \\
\text { adalah perlapisan batupasir, batulanau, batugamping, } \\
\text { serpih dan batubara. } \\
\text { Di bagian bawah singkapan berupa serpih- } \\
\text { batulempung dengan sisipan tipis batubara, ke arah } \\
\text { bagian atas berubah menjadi batugamping dengan } \\
\text { fragmen fosil foraminifera bentonik besar dan } \\
\text { beberapa fragmen batubara. Di bagian atasnya } \\
\text { dijumpai batulanu yang berubah menjadi } \\
\text { batulempung-serpih dengan sisipan batubara. Pada } \\
\text { lapisan atas dijumpai batupasir. }\end{array}$ & $\begin{array}{l}\text { terletak sekitar } 4,7 \mathrm{~km} \text { di bagian } \\
\text { barat area BNI-STP merupakan } \\
\text { lokasi penambangan batubara PT. } \\
\text { ENA. Morfologinya berupa } \\
\text { dataran-bergelombang. Singkapan } \\
\text { berupa tebing bukaan tambang. }\end{array}$ \\
\hline 15. & 462352 & $\begin{array}{c}98636 \\
69\end{array}$ & $\begin{array}{l}\text { Batupasir serpih, batubara, tambang batubara PT. } \\
\text { ENA }\end{array}$ & $\begin{array}{l}\text { terletak sekitar } 4 \mathrm{~km} \text { di bagian } \\
\text { barat area BNI-STP, lokasi } \\
\text { merupakan lokasi penambangan } \\
\text { batubara PT. ENA. Morfologinya } \\
\text { dataran-bergelombang. Singkapan } \\
\text { berupa tebing bukaan tambang. }\end{array}$ \\
\hline
\end{tabular}
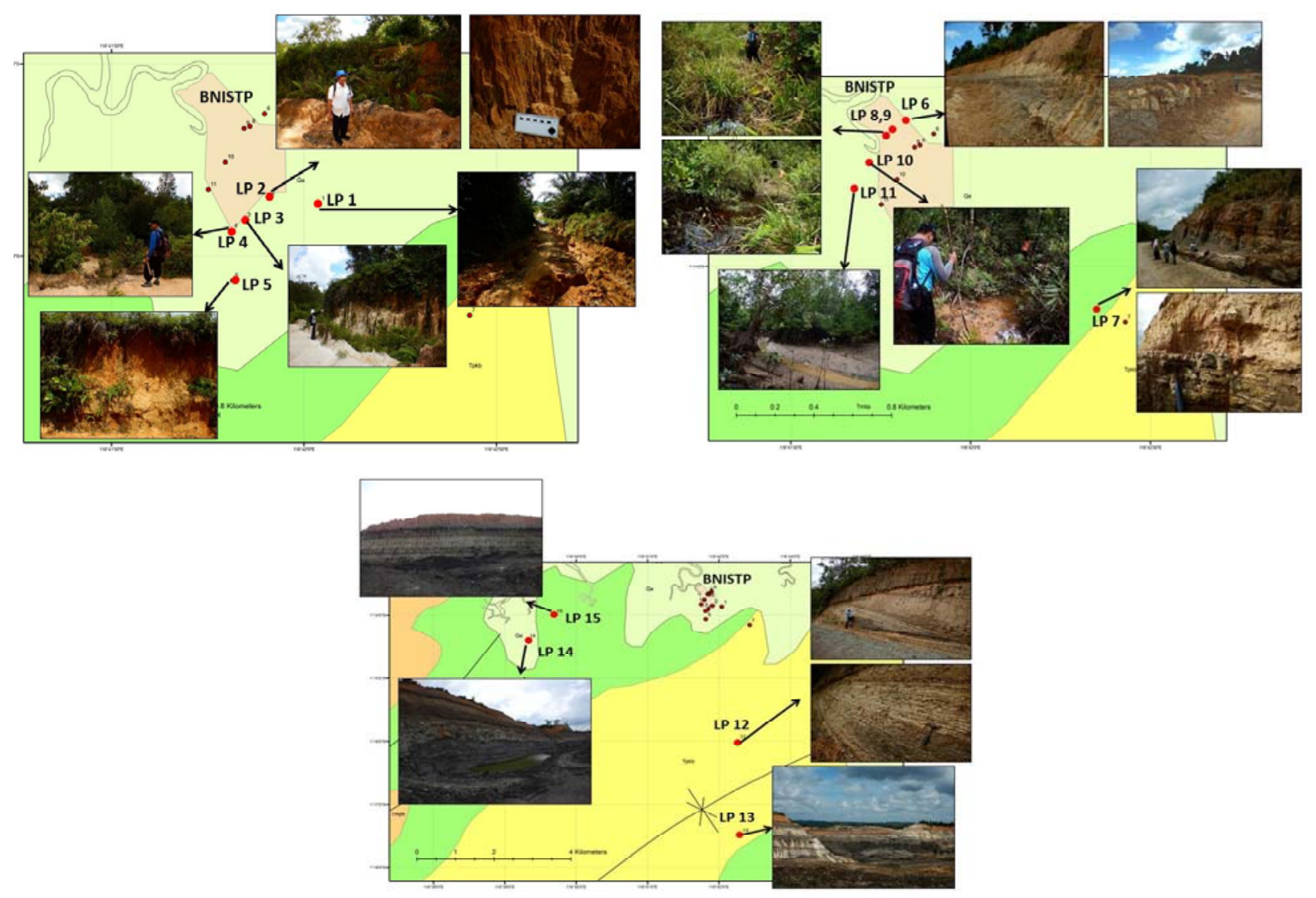

Gambar 6. Lokasi Pengamatan (LP) $1-15$. 
Daerah penelitian yang mempunyai Lipatan ini terjadi setelah pengendapan Formasi Kampung Baru pada masa Pliosen. Interpretasi tersebut didasarkan pada fakta bahwa Formasi Kampung Baru mempunyai kemiringan searah dengan besar sudut kemiringan yang relatif sama dengan Formasi Balikpapan di bagian bawahnya (Gambar 2). Sedangkan hasil pengamatan litologi lokasi penelitian ditunjukkan pada Tabel 1 .

Hasil perekaman data lapangan disajikan dalam sketsa dan pemerian litologi dan foto kondisi singkapan disajikan pada Gambar 6.
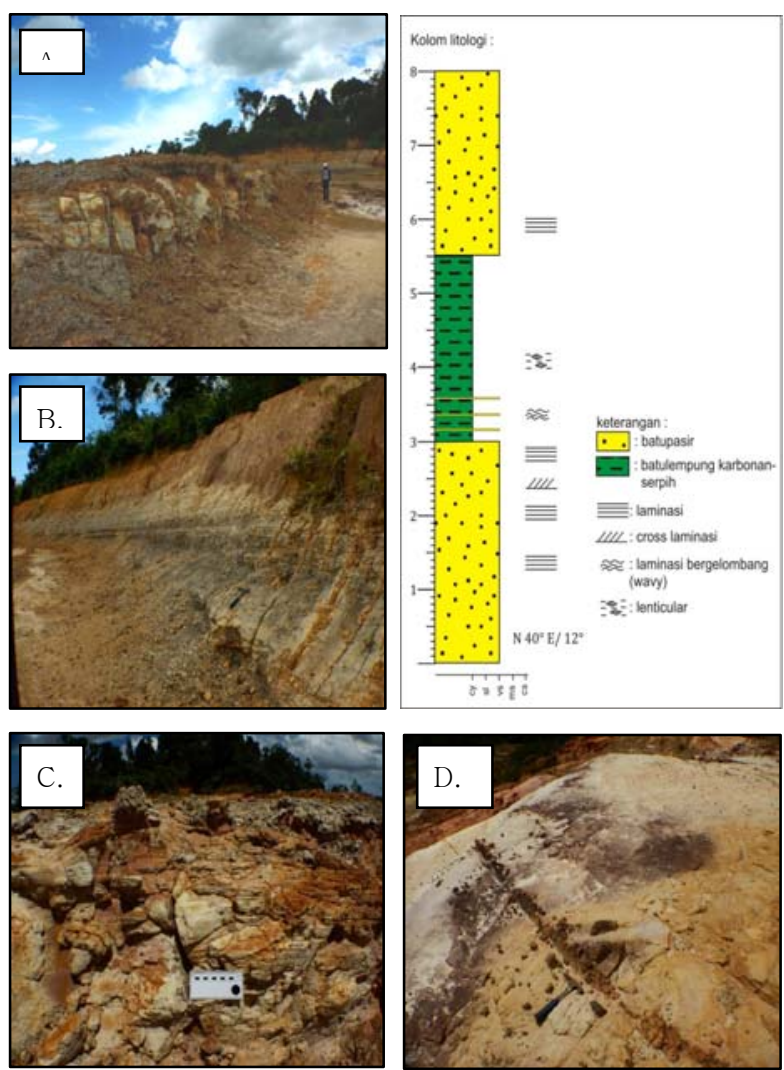

Gambar 7. Lokasi Pengamatan 6.

Morfologi daerah penelitian didominasi dataran, sebagian bergelombang dengan beberapa rawa, dan juga ada sebagian kecil berbukit (Gambar 6). Satuan litologi pada umumnya batupasir yang sudah mengalami proses pelapukan. Di dua lokasi pengamatan (LP 6 dan 7) data singkapan lapisan tanah adalah sebagai berikut:

(1) LP-6, struktur geologi berupa kekar dijumpai memotong seluruh perlapisan batuan (Gambar 7D). Sebagian singkapan bagian bawah batupasir (A). Singkapan tebing sebelah selatan berupa serpih berwarna hitam bagian atas ditumpangi batupasir (B). Singkapan batupasir menunjukkan struktur sedimen laminasi sejajar (C). Kekar berarah relatif utaraselatan terisi semen oksida besi (D).

(2) LP-7, singkapan berupa tebing bukaan jalan setinggi sekitar 10 m (Gambar 8A dan B) dan memanjang sekitar $60 \mathrm{~m}$.
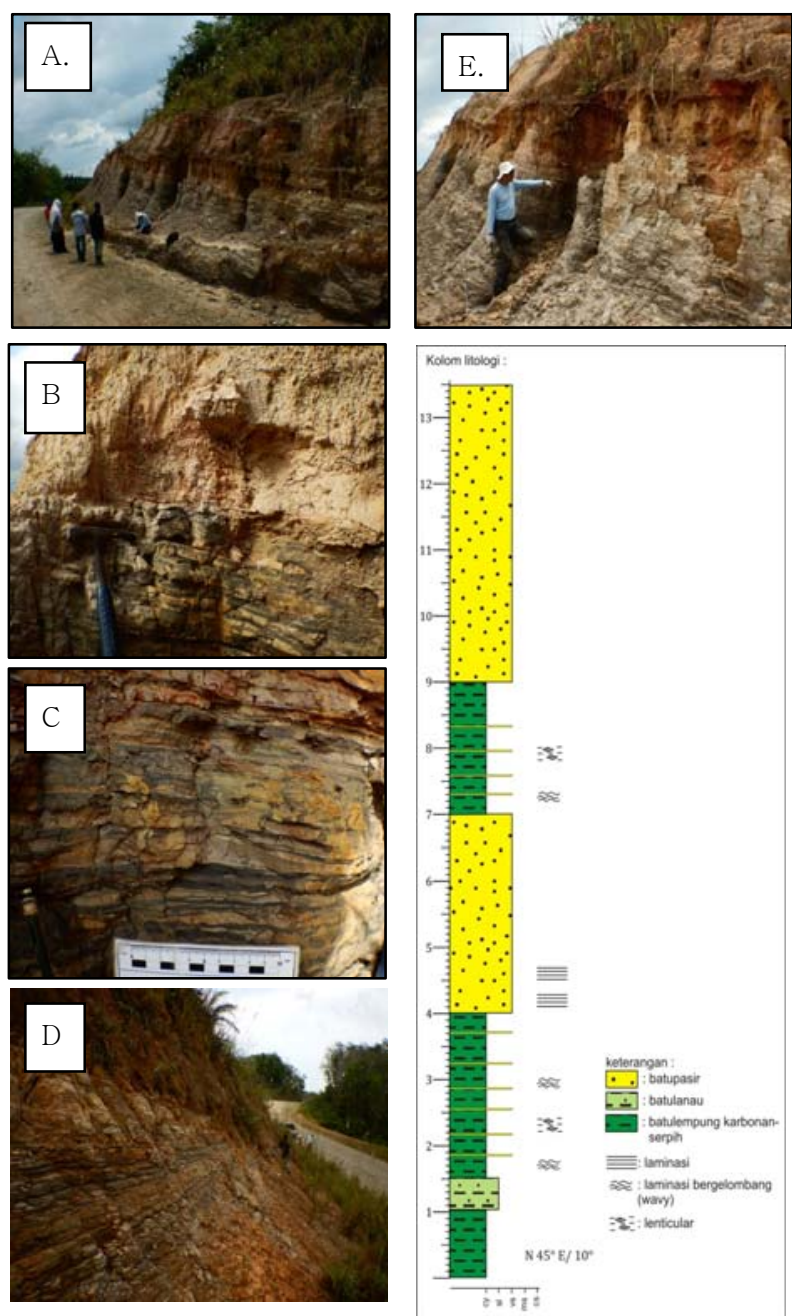

Gambar 8. Lokasi Pengamatan 7.

LP-7, sebagian kenampakan singkapan pada tebing sebelah timur berupa batulempung hitam yang diatasnya ditumpangi oleh batupasir (A,B). Kontak antara lempung hitam dengan batupasir di bagian atas (C). Struktur sedimen lentikuler-wavy bedding pada lapisan batulempung hitam (D). Singkapan batulempung hitam lapisan atas kontak dengan batupasir (E) Kedudukan perlapisan batuan adalah $\mathrm{N} 45^{\circ} \mathrm{E} / 10^{\circ}$ atau miring ke arah tenggara. Litologi di bagian bawah berupa serpih berwarna hitam.

Tebal dari lapisan serpih bagian bawah sekitar 1,5 m. Ke arah atas litologi berubah 
menjadi batulanau berwarna abu-abu dengan tebal $0,5 \mathrm{~m}$. Di bagian atas lapisan batulanau dijumpai batulempung hitam dengan sisipan batupasir sangat halus dengan tebal 2,5 m.

\subsection{Interpretasi Geologi Permukaan dan Bawah Permukaan}

Hasil interpretasi kondisi bawah permukaan diperoleh dengan membuat penampang geologi regional. Berdasarkan penampang geologinya diketahui bahwa daerah penelitian tersusun oleh Formasi Balikpapan yang sebagian ditutupi oleh endapan aluvial. Di bagian tenggara dari daerah penelitian, formasi ini ditumpangi oleh Formasi Kampung Baru.

Formasi Balikpapan tersusun oleh batupasir dengan batulempung dan sisipan serpih karbonan yang kemungkinan diendapkan pada lingkungan transisi pada saat Miosen Tengah. Perlapisan batuan relatif miring ke arah tenggara. Batuan yang telah tersingkap di permukaan sebagian besar telah mengalami pelapukan menjadi tanah berukuran pasir sangat halus - lempung.

Daerah penelitian yang mempunyai. Lipatan ini terjadi setelah pengandapan Formasi Kampung Baru pada saat Pliosen. Interpretasi tersebut didasarkan pada fakta bahwa Formasi Kampung Baru mempunyai kemiringan searah dengan besar sudut kemiringan yang relatif sama dengan Formasi Balikpapan di bagian bawahnya.

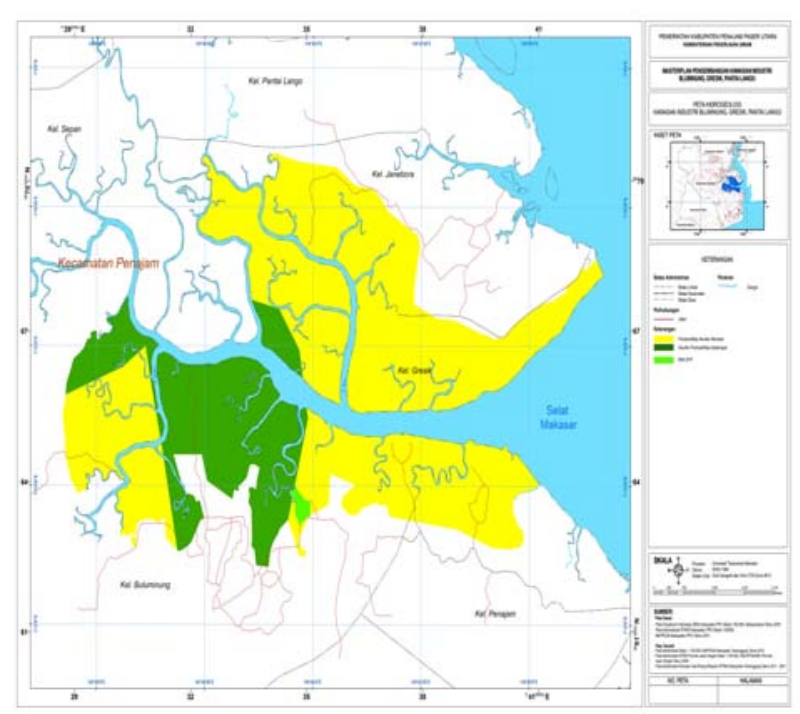

Gambar 9. Peta Hidrogeologi.
Sistem hidrogeologi daerah penelitian termasuk dalam kategori produktifitas akuifer rendah (Gambar 9). Kondisi hidrogeologi sangat dipengaruhi oleh lithologi batuan, seperti karakteristik akuifer perlapisan batuan dan keterdapatan sumber air[18].

\subsection{Pembahasan}

Kondisi geologi daerah BNI-STP berada di sebelah selatan dari Cekungan Kutai. Struktur geologinya berupa sesar mendatar dan lipatan, berarah baratlaut-tenggara merupakan sesar percabangan dari sistem Sesar Adang. Sesar ini aktif bergerak dengan pergerakan mendatar kiri pada saat Miosen. Hasil interpretasi peta Shuttle Radar Topografi Mission (SRTM) terlihat adanya pola kelurusan bukit yang relatif paralel dengan struktur utama berarah baratlaut-tenggara. Bukti struktur di lapangan menunjukkan kekar berarah $\mathrm{N} 175^{\circ} \mathrm{E}-\mathrm{N} 170^{\circ} \mathrm{E}$ dan bersifat terbuka. Kedudukan perlapisan pada beberapa lokasi pengamatan mengarah ke tenggara dan merupakan sayap dari lipatan berarah baratdaya-timurlaut.

Keberadaan struktur sesar di lokasi calon tapak dihindari karena dapat menyebabkan kerusakan infrastuktur apabila struktur sesar tersebut aktif bergerak. Penyelidikan awal ini tidak dijumpai bukti adanya pergerakan sesar sehingga diinterpertasikan sesar yang ada di area BNISTP dan sekitarnya tidak aktif. dan tidak memotong endapan berumur Kuarter.

Litologi penyusun utama daerah penelitian berupa batuan sedimen silisiklastik seperti batupasir, serpih. Tidak dijumpainya batuan primer asal kegiatan gunung api dibuktikan pula dengan kehadiran sisipan batubara serta batugamping. Oleh sebab itu, daerah penelitian diperkirakan terletak jauh dari tubuh gunung api. Berdasarkan peta geologi dan kesebandingan stratigrafi regional batuan yang dijumpai termasuk dalam Formasi Balikpapan.

\section{KESIMPULAN}

Kondisi geologi lingkungan daerah Buluminung mempunyai karakteristik morfologi berupa dataran-bergelombang 
dengan rawa-rawa di beberapa bagian. Litologi penyusunnya berupa batupasir-serpih, batubara dan batugamping yang termasuk dalam Formasi Balikpapan. Sebagian area ditutupi oleh endapan sungai lempung (alluvial) dan endapan rawa. Struktur geologi berupa kekar berarah relatif utara selatan dan struktur sayap lipatan yang berarah timurlautbaratdaya, terbentuk pada saat Mio-Pliosen. Di daerah studi ini tidak dijumpai indikasi adanya struktur tektonik aktif maupun vulkanisme aktif. Kondisi hidrogeologi masuk dalam kategori produktifitas akuifer rendah.

\section{UCAPAN TERIMA KASIH}

Ucapan terimakasih penulis sampaikan kepada Kepala Pusat dan Kepala Bidang Kajian Data Tapak PLTN-PKSEN yang telah mendukung kegiatan penelitian ini, serta rekan-rekan di bidang Kajian Data Tapak. Terima kasih juga, disampaikan kepada pihak BAPPEDA Kabupaten Penajam Paser Utara dan Balitbangda Provinsi Kalimantan Timur yang telah membantu terlaksananya kegiatan penelitian di Kabupaten Penajam Paser Utara, Kalimantan Timur.

\section{DAFTAR ACUAN}

[1]. — 'Draft Laporan Akhir Master Plan Pengembangan Kawasan Industri BuluminungGersik-Pantai Lango", BAPPEDA Kabupaten Penajam Paser Utara, Kalimantan Timur, 2016.

[2]. Rencana Tata Ruang Wilayah Propinsi Kalimantan Timur tahun 2016-3026, Samarinda, Peraturan Daerah Provinsi Kalimantan Timur No. 01, 2016.

[3]. Mardha A., Huda K., dan Ridwan A.A., "Program Peraturan Dalam Pengawasan PLTN Untuk Menyongsong Pembangunan PLTN", Prosiding Seminar Keselamatan Nuklir, 2006, hal. 613-626.

[4]. Site Evaluation for Nuclear Installation, Safety Requirements No. NS-R-3, IAEA Safety Standards Series, IAEA, 2003.

[5]. Gusti Warman, I Gde Budi Indrawan, Dwi Agus Kuncoro, "Studi Karakteristik Geologi dalam Perencanaan dan Penentuan Lokasi Bangunan Pelimpah Darurat di Waduk Jatigede, Sumedang, Jawa Barat", Prosiding Seminar Nasional Kebumian ke 7, Yogyakarta 2014.

[6].___ "Laporan Penelitian Dukungan Teknis Survei Tapak PLTN Kalimantan”, Pusat Kajian Sistem Energi Nuklir-BATAN, Jakarta, 2017.

[7]. Alaudin. (November 2017). Geologi Regional Lembar Balikpapan, Kalimantan [Online]. Available:

http://www.amuzigi.com/2016/05/geologi- regional-lembar-balikpapan-

kalimantan.html? $\mathrm{m}=0$,

[8]. Hidayat S., \& Umar I., "Peta Geologi Lembar Balikpapan skala 1:250.000”, Direktorat Survey Geologi, Bandung, 1994.

[9]. Wain, T. and Berrod, B., "The Tectonic Framework and Paleogeographic Evolution of The Upper Kutei Basin", Proceedings of the Indonesian Petroleum Association $18^{\text {th }}$ Annual Convention, 1989.

[10]. Satyana A.H., Adang-Lupar, "Mega Fault, Kalimantan: Controversies and New Observations On The Trans-Kalimantan Megashear", Pertemuan Ilmiah Tahunan Ikatan Ahli Geologi Indonesia ke 25, 1996.

[11]. Moss S.J and Chambers, J.L.C., "Tertiary facies architecture in the Kutai Basin, Kalimantan, Indonesia". Journal of Asian Earth Science, Vol.17., 1999, pp. 157-181.

[12]. Nuay E.S., Astarita A.M., Edwards K., "Early Middle Miocene Deltaic Progradation in The Southern Kutai Basin", Proceedings Indonesian Petroleum Association 36th Annual Convention, 1985, pp. 63-81.

[13]. Susianto A., Esomar E.R., Rahadi R., and Ardhi M.N, "The Characteristics of the Sepinggan Strike Slip Fault Zone And Its Role In Forming Structural Traps The Southeast Kutei Basin”, Proceedings Indonesian Petroleum Association Thirty-sixth Annual Convention, 2012, pp. 55- 78.

[14]. Kurnia Anzhar, Fepriadi, Ajat Sudrajat, "Kajian Nilai Percepatan Tanah Maksimum di Daerah Interes untuk Tapak Pembangkit Listrik Tenaga Nuklir (PLTN) Provinsi Kalimantan Timur", Prosiding Seminar Nasional Pengembangan Energi Nuklir III, Jakarta, 2011,.

[15]. __, (2017, April 20). SRTM 1 arc second [Online] Available: http;//Earthexplorer.USGS.gov.

[16]. Cloke I. R., Craig J., dan Blundell D.J., Structural controls on the hydrocarbon and mineral deposits within the Kutai Basin, East Kalimantan, in Fractures, Fluid Flow and Mineralization, Special Publication, 155, London, Geological Society, 1999, pp. 213-232.

[17]. Setijadji, L.D., Basuki, N.I., Prihatmoko, S., "Kalimantan Resources: an Update on Exploration and Mining Trends, Synthesis on Magmatism History and Proposed Models for Metallic Mineralization", Pertemuan IImiah Tahunan Ikatan Ahli Geologi Indonesia ke 39, 2010.

[18]. Ibnu Hasyim, Heru Hendrayana, Arifudin Idrus, "Perbedaan Karakteristik Kimia Air dan Mineralogi Batuan pada Formasi Balikpapa dan Kampungbaru pada Tambang Batubara, Daerah Kutailama, Kecamatan Anggana, Kabupaten Kutai Kartanegara”, Prosiding Seminar Nasional ReTII, STTNAS, Yogyakarta, 2015 